Article

\title{
The Effect of Customer Participation Types on Online Recovery Satisfaction: A Mental Accounting Perspective
}

\author{
Yu Zhang and Bingjia Shao * \\ School of Economics and Business Administration, Chongqing University, Chongqing 400030, China; \\ lovezym2000@163.com \\ * Correspondence: shaobingjia@cqu.edu.cn; Tel.: +86-177-2377-3387
}

Received: 12 September 2018; Accepted: 1 October 2018; Published: 3 October 2018

\begin{abstract}
With the high popularity of the Internet, online trading has gradually replaced the traditional shopping model and extended to every corner of social life. However, online trading cannot avoid failures; thus, understanding how firms can best recover customers in online contexts to keep customer loyalty is very important. This study investigates the mechanisms by which customer participation types (physical, mental, and emotional) promote customers' perceived justice and post-recovery satisfaction from a mental accounting perspective. Furthermore, the moderating effects of two modes of online apology speech acts (direct and indirect) on customer participation and perceived justice are investigated. A total of 1083 Chinese tourists who have purchased a Wi-Fi rental service in the past year were contacted according to the database provided by two travel agencies, and 329 stated having experienced an online recovery service and participated in the survey; 297 valid questionnaires were collected. Among them, $48.82 \%$ were males and $51.18 \%$ females. Most of the respondents were aged 20-35 years. By carrying out data analysis by partial least squares structural equation modeling (PLS-SEM) using SmartPLS, the results show that, first, only mental and physical participation can enhance perceived justice, while emotional participation does not influence perceived justice. Second, the positive influence of mental participation on perceived justice is most significant. Third, only when the service staff adopts the indirect mode to express an online apology, mental and physical participation can enhance perceived justice.
\end{abstract}

Keywords: customer participation; mental accounting; online apology speech acts; perceived justice; post-recovery satisfaction

\section{Introduction}

The ubiquity of the Internet and social media has enabled customers to engage more with companies and other customers online and has made it easier for customers to complain about service failures [1]. Thus, understanding how firms should best recover customers in online contexts has become an important topic for both researchers and practitioners [2-4].

Past studies in online recovery indicated that the recovery strategies in offline recovery, such as tangible recovery strategies (e.g., compensation, discounts) $[5,6]$ and intangible recovery strategies (e.g., apologies, empathy, politeness) [4], are likely to be highly applicable in online recovery [2,7]. However, customer participation, which is an important and novel offline recovery strategy to enhance customers' perceived justice and post-recovery satisfaction, has largely been overlooked in the online recovery context [2].

Moreover, Chua and Sweeney [8] have concluded that the extent of customer participation is not an obviously black and white distinction but is more suited for measurement along a continuum of 
different behaviors; however, extant studies in service recovery have investigated the effectiveness of customer participation typically using a dichotomous (participation or not) or trichotomous (firm, joint and customer recovery) construct that reflect only the extent of the effect of customers' labor input on service performance. Such a construct does not clearly explain the different effects on service interaction of the different behaviors exhibited during customer participation [8,9], and it creates room for potential errors in measuring reliability [10]. In particular, different participation behaviors characterize the different roles that customers take in service performance, e.g., substituting for service employees' work or undertaking the responsibilities that they should bear, and they indicate different participation purposes, e.g., for guaranteeing normal service production or service enhancement [11]. Thus, different types of customer participation may induce different effects on service outcome $[11,12]$. Mental accounting provides an ideal lens for analyzing this inference because this theory describes how customers take resources that are categorized into different accounts and given different values [13]. Thus, here, we verify this inference based on mental accounting theory to explain whether different types of customer participation (i.e., physical, mental, and emotional participation) have different effects on perceived justice and post-recovery satisfaction.

Additionally, the employee's emotional intelligence is highly related to the customer's evaluation of recovery performance [14], e.g., an employee's ability to provide an apology with sincerity and empathy is essential to achieving the customer's forgiveness [15] and a positive evaluation of customer participation [16]. However, there has been a lack of attention on how to promote this ability in employees [14]. In particular, unlike traditional human interaction, due to a lack of non-verbal communication and social contextual cues in the online environment, the employee's interpersonal and emotional stances cannot be fully expressed through text-based language during online interaction [17], resulting in a reduction in the perception of the employee's empathy and sincerity [3]. Thus, how to break through these constraints that text-based language imposes on expressers is an important problem that needs to be resolved. Danesi [18] has concluded that the widespread use of online language such as emojis has greatly relieved this problem in informal conversations because an emoji can give online messages a more emotive-phatic function. However, whether emojis can produce the same positive effect in formal conversations such as those involving online recovery is uncertain. Therefore, this study specifically explores the extent to which the manner of apology speech acts (the use of text to directly express an apology versus the use of an emoji to do so) has a moderating effect on customer participation and perceived justice to assess the effects of the linguistic factors arising in online recovery.

Overall, this study addresses a gap in the existing research that stems from ignoring the effect of customer participation types on the service outcome in service recovery. This study extends the existing research on online recovery by exploring the moderating role of linguistic factors in customer participation and perceived justice in the online environment. This study provides recommendations that can be applied by online service providers to enhance online recovery management.

\section{Theoretical Background}

\subsection{Customer Participation}

\subsubsection{The Dimensions of Customer Participation}

Customer participation refers to "the extent to which customers are involved in service production and delivery by contributing effort, knowledge, information and other resources" [19], and the contribution of customers is thought to be multidimensional [20]. Extensive existing research on the construct of customer participation has been conducted, but there is no definitive and singular consensus. As shown in Table 1, there are four categories regarding the dimensionality of customer participation, but regardless of how many factors are included in these structures, the studies on the subject all suggest that mental, physical and emotional labor are the three basic resources that customers may contribute to service performance [9,10,21-23]. However, existing service recovery 
studies always use a dichotomous or trichotomous construct to manipulate the different extents of customer participation (e.g., [2,15,24]), which may cause potential errors in measuring reliability [10] because it is difficult for participants to associate words with all the resources they need to spend in participation. This difficulty also may be the reason why some empirical findings show that the impact of customer participation on service outcomes is not always positive, e.g., [25-27]. The study of [27] concluded that only when the benefits are greater than the resources they invested will customer participation lead to positive service outcomes, and this means when the customer is unable to properly evaluate the resources required in the experimental scenario, the customer's assessment of the benefits will become difficult, resulting in inconsistent empirical findings about the impact of customer participation. Thus, it is necessary to know which personal resource inputs of customers are more likely to enhance the positive effect of customer participation.

Table 1. Examples of customer participation composition in the literature.

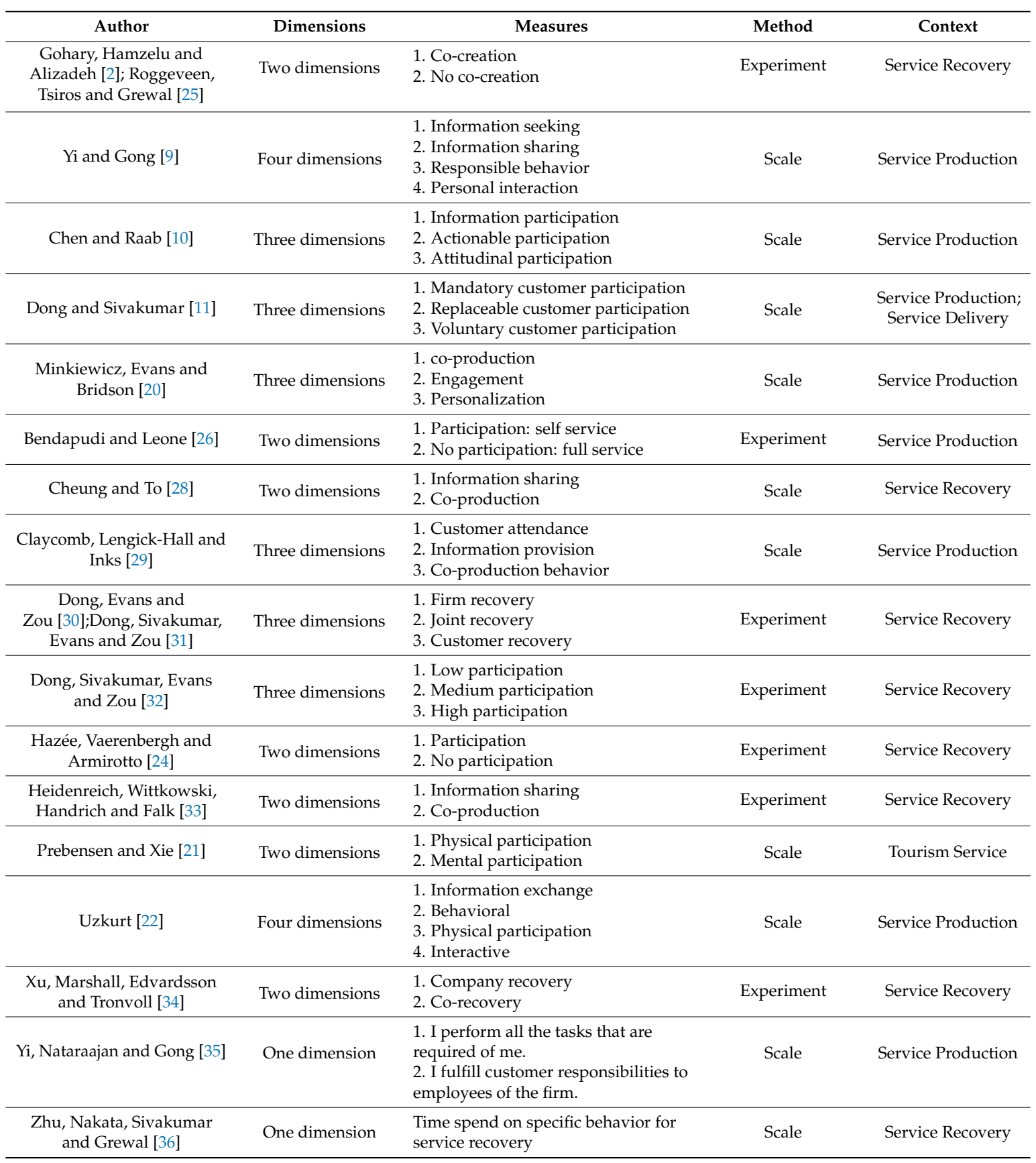


According to Koc et al. [37], we divided customer participation into three dimensions: physical, mental and emotional participation. The reasons why we choose this construct to undertake further research are twofold: first, this construct has been used to research the effect of the three types of resource inputted in service production on service recovery outcomes [37], which is closer to this study's research background. Second, the study of [37] concluded this construct can give an intuitive and comprehensive description of the three resources of customer participation, and the aim of this study is to investigate the impact of different resources which customer input in the service recovery on recovery outcome; thus, we think this construct is more in line with our research topic. Here, mental participation is "perceptual behavior" and refers to efforts made by the customer to study, accumulate, and share information and knowledge [21,37]. Physical participation is "actual behavior" and refers to the investment of the customer's own tangible assets and the amount of effort put into the actions taken [21,37]. Emotional participation is "actual expression" and refers to the attitude conveyed by the customer during his/her participation in online recovery [10,37].

\subsubsection{Customer Participation in Service Recovery}

Dong, Evans, and Zou [30] first introduced customer participation in service recovery and defined it as "the degree to which the customer is involved in taking actions to respond to a service failure". Scholars have verified that customer participation can lead to positive post-recovery behavior, such as perceived service quality [32], satisfaction and repurchase intention [25,34], positive word of mouth [16,38], experience with service recovery [39], and intention for future co-creation [31,40].

Because customer participation can bring the above advantages, scholars have found that customer participation can enhance the effect on customers' cognition, including perceived justice [2,25,28,39,41], perceived match [31], perceived value [41], perceived control [42], and perceived co-creation [38]. Furthermore, positive and negative emotions [43] and affect [44] have been used to explain the role of customer participation in customers' emotions. Additionally, the roles of recovery effort [36] and customer participation readiness [32] have been discussed to better understand the impact of individual factors on the effect of customer participation.

The moderator variables that can influence the positive relationship between customer participation and post-recovery evaluation have also been studied, including the customer's attitude about co-recovery [25], the initiator of co-recovery [34], recovery urgency [31], brand equity [24], culture [40], and recovery process communication [16]. However, Dong and Sivakumar [11] have noted that existing studies on customer participation pay less attention to the moderators, especially employees' personal resources, such as their communication style and emotional intelligence [16]. Limited studies have explored the moderating role of employees' personal resources in customer participation and the service outcome [16]. Thus, in this study, we use speech act theory to analyze the moderating role of employees' different expressive modes of apology in customer participation and perceived justice in online recovery.

\subsection{Mental Accounting: Bridging the Relationship between Customer Participation and Perceived Justice}

"Justice" is the yardstick by which customers measure their satisfaction with purchasing processes [28]. In the context of service recovery, perceived justice is how a customer experiences justice of treatment by a company during service recovery [45], and it is an important standard by which customers evaluate the quality of the recovery strategy [3]. As noted in the introduction, the relationship between customer participation and perceived justice has been verified $[25,28,34,41]$; however, prior research lacks a theory-driven model to consider whether different types of customer participation (i.e., physical, mental or emotional) have different effects on perceived justice. To address this gap, this article draws on mental accounting theory to develop the research hypotheses discussed in the following.

Mental accounting is defined as "the set of implicit cognitive operations used by individuals and households to organize, evaluate, and keep track of financial activities" [13]. Mental accounting 
research finds that people unconsciously put wealth into different accounts for management and that different mental accounts have different accounting methods and calculation rules. This phenomenon reveals why individuals often make decisions in an unexpected way, such as when an individual's decision contradicts the simplest rational economic rule. In mental accounting theory, Thaler [13] highlights three components of mental accounting: the labeling of activities for specific accounts, the framing of gains and losses, and the frequency with which accounts are evaluated [43]. In this paper, we mainly focus on labeling as a core mental accounting issue that has several testable implications for understanding the influence of customer participation types on perceived justice.

Labeling is fundamental to mental accounting because individuals must label resources to remember and track them, which then affects the individual's calculation of gains and losses and making of unexpected decisions $[13,43]$. According to mental accounting, in principle individuals always treat their resources equally; in fact, however, they treat them unequally. For example, the results of losing a 200 RMB music ticket and a 200 RMB telephone card before watching a concert are different, although both scenarios involve a loss of 200 RMB. People in the former scenario are unlikely to spend 200 RMB to make up for the ticket, while in the latter, they will continue to watch the concert [44]. Therefore, labeling does not lead to aggregate resources and freely arbitraging among them; rather, it produces a systematic biasing of resource valuations [43].

Combined with customer participation, that is, for individuals to categorize their own resources into different mental accounts, customers will value the different types of resources that they input in service recovery differently. Prelec and Lowenstein [46] noted that individuals match the pleasures of consumption with the pains of paying; similarly, only when the service staff provide appropriate recovery strategies that match customers' contributions will customers feel that they have received fair treatment. Thus, different resource valuations may make customers produce different perceptions of pay and gain, leading to different perceptions of justice.

\subsection{Apology Speech Acts}

The apology speech act can be defined as "a speech act which is intended to provide support for the hearer who was actually or potentially malaffected by a violation" [47]. Searle [48] categorized apologies as expressive speech acts. Apology speech acts are an increasingly important topic in the fields of linguistics and sociolinguistics, and widespread research has been carried out in this area. Research demonstrates that apologies are capable of acting as effective tools in managing interpersonal conflict [49-51]; they are also an effective strategy that can be adopted by companies in public relations crisis aversion [52] and service recovery [2,15,45].

As suggested by Austin [47], for speech acts to be successfully applied, the listener must possess an understanding or appreciation of the extra-verbal force in respect of the speech act carried out by the speaker. That is, only when the apology can exert stimulus control over the listener's forgiving response can the apology be referred to as a sufficient apology [53]. Several studies have found that the emotional response, which is most likely to produce a forgiving response from the listener, is the most important feature of apologies [15,49,51]. Emotional responses can be described in terms of whether the expression of the apology contains the speaker's sincerity, genuineness, remorse, regret or guilt, and it is always performed non-verbally, such as through facial expressions, signs of fear, and stance [53]. However, in the online recovery context, remote communication makes it difficult to show the emotional response of the apology non-verbally [7], and the asymmetric relationship between the customer service demand and supply also causes the customer to question the emotional response of the service staff's apology [15]. Thus, which form of expression can better show the emotional response to the customer is an important issue in online recovery. In particular, the role of customers has been regarded as that of a "partial employee" [34], which means that an employment exchange relationship is also established between the customer and the service provider; thus, when customers' work effort and contributions are not matched with the appropriate responses from the service provider (e.g., compensation, benefits, apologies, identification), the exchange is 
unlikely to be considered just [54]. Therefore, we infer that an appropriate apology will influence the relationship between customer participation and perceived justice.

As Searle [48] noted, speech acts can be performed either directly or in various indirect ways, and Holtgraves [55] also proved that the choice of the way in which speech acts are performed (direct vs. indirect) will influence the encoding process of social information and lead to an effect on the listener's perceived politeness of the speaker. Thus, in this vein, we infer that the way of expression (direct vs. indirect) will also influence customers' perception of the emotional response of the apology, moderating the relationship between customer participation and perceived justice. Metaphor is an important form of indirect expression [47], and Danesi [18] regarded emojis as specific expressions of conceptual metaphors; for example, " $\mathscr{\theta}$ " is a conceptual metaphor that represents that the speaker is expressing sadness. Thus, in this study, we take the " $\bullet$ " used by the enterprise to express an apology as an indirect expression [18], with "Sorry" being a direct expression [48,51,55].

\section{Hypothesis Developments}

\subsection{Customer Participation and Perceived Justice}

Emotional labor is often viewed as a resource loss, and it always makes employees feel pressure because they need to keep their emotional expression suitable through self-regulation [56]. In particular, when the employee's emotional labor is "surface acting" rather than "deep acting", the employee will feel more pressure [57]. Similarly, customers' emotional participation also brings pressure since emotional participation means that they are controlling anger and frustration in the face of failure and using politeness and a patient attitude to interact with service staff [40]. However, Dong et al. [31] have concluded that customer participation cannot produce a positive effect when customers are under pressure. Therefore, we infer that emotional participation cannot facilitate promoting customers' perceived justice.

Additionally, Park and Ha [41] have found that when customers actively exchange operant resources such as knowledge, information and skills with the service provider, the customer will think that customer participation can create higher utilitarian value and hedonic value. In other words, when customers mobilize the necessary mental resources and reconfigure the procedure and content of the service recovery, this process will enhance their self-efficacy and self-evaluation, promoting customers' perceived justice [41]. Thus, we infer that mental participation has a positive effect on perceived justice.

To avoid the regret and disappointment from having wasted their time, individuals always undervalue their time resources [43]. Thus, customers may not be sensitive to the time and energy that they have invested in service recovery. Dong et al. [30], Hazée et al. [24] and Xu et al. [34] have verified this point by manipulating customers' physical participation in experiments. They found that customers are willing to carry out actual behaviors to facilitate service recovery and that customers' physical participation can reduce the uncertainty of the recovery outcome [57] and provide an informed choice to the customer, which will help him/her believe that participation is a collaborative process and lead to a positive evaluation of the effort of the service provider [41]. Thus, we infer that physical participation has a positive effect on perceived justice. We propose the following hypotheses:

Hypothese 1a. Emotional participation does not have a positive effect on perceived justice.

Hypothese $1 \mathbf{b}$. Mental participation has a positive effect on perceived justice.

Hypothese 1c. Physical participation has a positive effect on perceived justice. 


\subsection{The Moderating Effect of Apology Speech Acts}

Resource exchange theory conceives interpersonal behavior as "a channel for resource transmission" and that people always strive to acquire and preserve resources to minimize resource losses and achieve resource balance [52,58]. Thus, customer participation will lead to the depletion of resources, and if the customer wants to achieve a balance, then he/she will look forward to receiving a return from the service provider to make up for the loss. Social interaction can be viewed as the trading of emotional goods; these goods are generated by the expectation of mutual benefit, and personal positive feedback is a kind of emotional good [51,52]. Thus, the service staff's positive emotional feedback can help customers obtain compensation for resources, which can make the relationship between the customer and service staff reciprocal.

However, in the online environment, the lack of non-verbal communication and social context cues experienced within the computer-mediated communication mode of the "cues-filtered-out approach" restricts the interlocutor's expression of emotional and interpersonal stances [17] and influences customers' positive judgments and perceptions generated from language, which will make the customer doubt the sincerity of the feedback from service staff $[3,15]$. Thus, the adoption of a direct expression of apology will break the reciprocal relationship between the customer and the service staff, making the customer emphasize his/her own effort, reducing the positive evaluation of employees' efforts, and leading to a low perception of justice.

Nevertheless, emojis are capable of making up for the lack of flexibility encountered with pure text-based communication in the online environment, enhancing the social significance and emotiveness of inert text-based information [18]. This capability helps maintain the reciprocal relationship between the customer and the service staff and enhances the customer's impression that his/her own contribution is worthwhile and will receive a corresponding return. Furthermore, emojis can reduce the vagueness of information, even for customers of different ages or who do not frequently use emojis in online interaction [59].Thus, the emoji " $\bullet$ " can make different kinds of customers interpret the apology correctly and enhance the perception that the information forming the apology is authentic, improving customers' evaluation of the level of effort put into the service solution provided by the company and increasing their overall perception of justice [41].

Thus, we propose the following hypotheses:

Hypothese 2a. Compared to direct expression, indirect expression can better enhance the positive relationship between emotional participation and perceived justice.

Hypothese $\mathbf{2} \mathbf{b}$. Compared to direct expression, indirect expression can better enhance the positive relationship between mental participation and perceived justice.

Hypothese 2c. Compared to direct expression, indirect expression can better enhance the positive relationship between physical participation and perceived justice.

\subsection{Perceived Justice and Post-Recovery Satisfaction}

It has been demonstrated in numerous service-related studies that perceived justice has a direct and positive effect on customer satisfaction $[34,41]$ and that post-recovery satisfaction is an expression of the response to the perceived results and a positive expression of the customer with respect to the service recovery [16], providing us with an index through which we can evaluate recovery performance $[30,36,41]$. Thus, we propose the following hypothesis:

Hypothese 3. Perceived justice has a positive effect on post-recovery satisfaction.

We present the research model in Figure 1. 


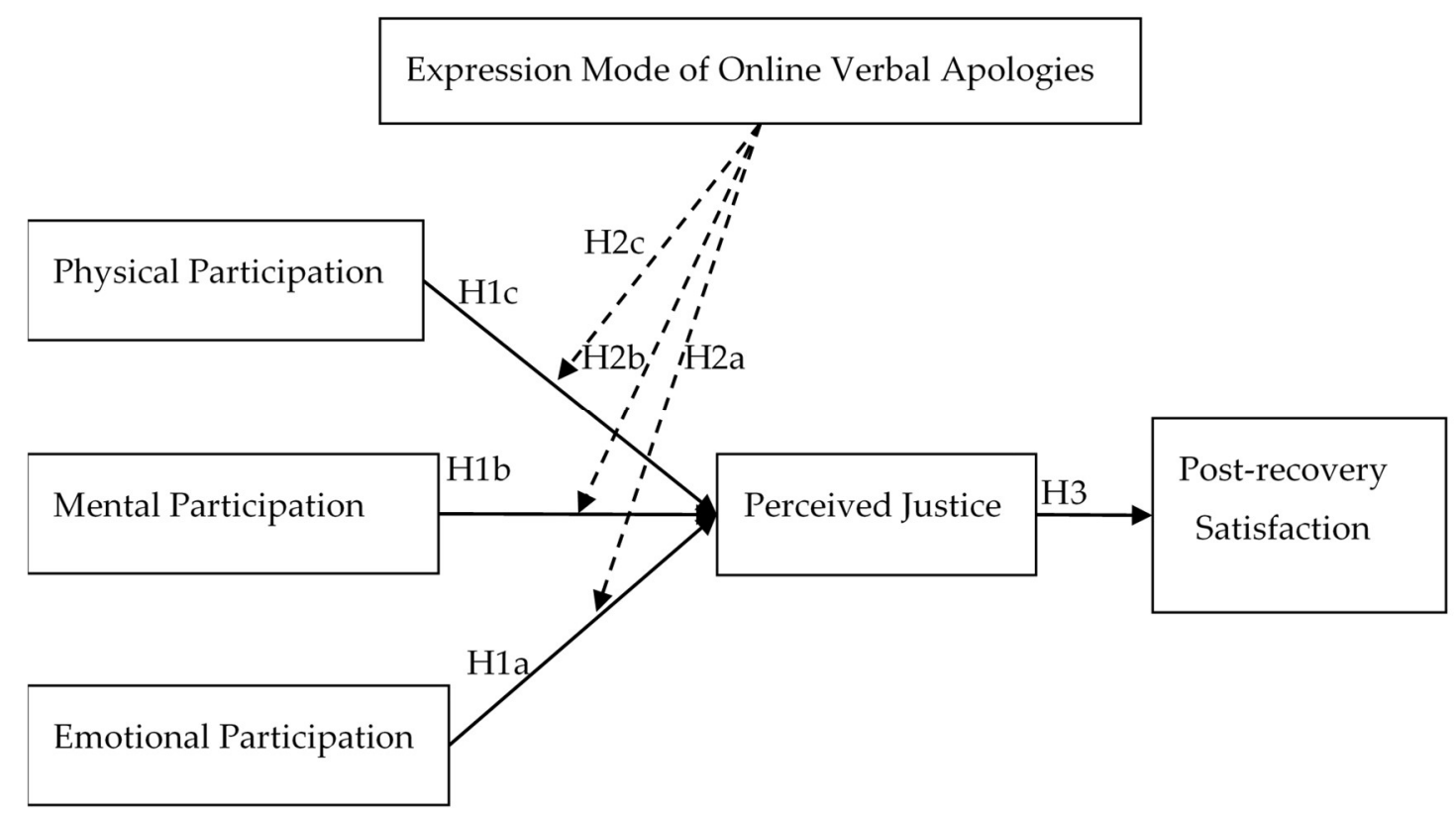

Figure 1. Research model. Note: H is the abbreviation for "Hypothese".

\section{Research Methodology}

A questionnaire was developed to test the research model empirically. Here, we take a Wi-Fi rental service provided when traveling outside of China as the research subject, because this product only provides online recovery based on their enterprise's WeChat subscription, and a market survey of 12 travel agencies in Chongqing from September 2017 to December 2017 shows that although this product is preferred by tourists because of its high quality and competitive price, tourists' complaints about the product's online recovery quality have been numerous, corresponding to a severe impact on the overall perceived service quality and repurchase intention. Therefore, solving the problem of online recovery failure has become the management focus of this product market, and we try to explain this problem through this study.

\subsection{Instrument Development}

First, we designed the measurement items for different expressions of apology based on the three basic elements of a complete apology, that is, the expression of apology, the acceptance of responsibility, and the repair [51]. The description and example of these three elements are shown in Table 2. Thus, based on the examples, we constructed two different expressions of apology, both of which meet the requirements of a complete apology (see Table 2). 
Table 2. The sample of the different expressions of apology.

\begin{tabular}{|c|c|c|c|c|c|c|}
\hline \multirow{3}{*}{ Apology Elements } & \multirow{3}{*}{ Description } & \multirow{3}{*}{ Example in Schumann (2014) } & \multicolumn{4}{|l|}{ Examples in Our Study } \\
\hline & & & \multicolumn{2}{|l|}{ Group 1 (Direct) } & \multicolumn{2}{|l|}{ Group 2 (Indirect) } \\
\hline & & & Elements & Measurement & Elements & Measurement \\
\hline $\begin{array}{l}\text { Express regret or } \\
\text { apology. }\end{array}$ & $\begin{array}{l}\text { Express a statement of apology or } \\
\text { express regret or sadness about } \\
\text { one's actions. }\end{array}$ & $\begin{array}{l}\text { "I'm sorry"; "I apologize"; } \\
\text { "I regret it" }\end{array}$ & "I am sorry" & \multirow{3}{*}{$\begin{array}{l}\text { I am sorry for the } \\
\text { inconvenience caused by } \\
\text { the equipment problem. } \\
\text { I will try to resolve this } \\
\text { problem as soon } \\
\text { as possible }\end{array}$} & “Ӫ, & \multirow{3}{*}{$\begin{array}{l}\text { “, this equipment problem } \\
\text { must bring you } \\
\text { inconvenience. I will try to } \\
\text { resolve this problem as soon } \\
\text { as possible" }\end{array}$} \\
\hline $\begin{array}{l}\text { Acceptance of } \\
\text { responsibility. }\end{array}$ & $\begin{array}{l}\text { State the offense using } \\
\text { responsibility-accepting language } \\
\text { or state that one accepts } \\
\text { responsibility for offense. }\end{array}$ & $\begin{array}{l}\text { "I'm truly sorry for breaking my } \\
\text { promise"; "I take full } \\
\text { responsibility for my words" }\end{array}$ & $\begin{array}{l}\text { "I am sorry for the } \\
\text { inconvenience caused by the } \\
\text { equipment problem" }\end{array}$ & & $\begin{array}{l}\text { “, this equipment } \\
\text { problem must bring you } \\
\text { inconvenience." }\end{array}$ & \\
\hline Repair. & $\begin{array}{l}\text { Attempt to repair the damage or } \\
\text { offer to compensate for or fix the } \\
\text { problem caused by the offense. }\end{array}$ & $\begin{array}{l}\text { "I will make sure that I } \\
\text { remember to call this week"; } \\
\text { "I love you and I am eternally } \\
\text { grateful for all you've done" }\end{array}$ & $\begin{array}{l}\text { "I will try to resolve this } \\
\text { problem as soon as possible" }\end{array}$ & & $\begin{array}{l}\text { "I will try to resolve this } \\
\text { problem as soon as } \\
\text { possible" }\end{array}$ & \\
\hline
\end{tabular}

Note: the italicised words indicate the location of the element in the sentence. 
The question "To which do the actual statements used by the staff belong?" is taken to measure which form of expression the staff used in the most recent online recovery. The measurement questions for the remaining variables are adapted from the literature to ensure the validity of the scale.

Following the approach suggested by Douglas and Craig [60], the questionnaire was evaluated by back translation to ensure the equivalence of scales and to avoid misunderstanding and misinterpretation. The questionnaire was first translated into Chinese by two Chinese/English bilingual experts. Then, the Chinese questionnaire was translated into English by two different Chinese/English bilingual experts. The original and back-translated versions were given to a bilingual judge to determine the validity of the scales. At last, the Chinese questionnaire was used to collect data in the pre-test and formal test.

Approval from the Chongqing University Ethics Committee was obtained prior to initiating the survey. Chongqing University Ethics Committee was formed by the graduate school of Chongqing University and consisted of 9 members, and this study was supported by a full vote. Furthermore, all the participants have been informed about the purpose of this survey is to better understand the quality of online services and prior consent for the survey was obtained by emphasizing the investigation as voluntary before them answered the questionnaire.

A pre-test was conducted to validate the instrument, and different expressions of apology were manipulated through three more questions: “The speaker expresses an apology indirectly by using network language", "The speaker expresses the apology directly by saying sorry", and "This statement shows that the speaker is aware that he/she should take responsibility for the problems that happened".

We invited 40 participants whose mother tongue is Chinese to answer the pretest questionnaire on a website, and the results showed that the two statements can correctly describe the different expressions of apology. The "Indirect Expression" thought the service staff expressed an apology indirectly $\left(\mathrm{M}_{\mathrm{IDE}}=4.350, \mathrm{M}_{\mathrm{DE}}=2.450, \mathrm{~F}_{(1,38)}=58.374, p<0.001\right)$, and the "Direct Expression" thought the service staff expressed an apology directly $\left(\mathrm{M}_{\mathrm{DE}}=4.200, \mathrm{M}_{\mathrm{IDE}}=1.700, \mathrm{~F}_{(1,38)}=110.981, p<0.001\right)$. Both $\mathrm{s}$ thought the service staff admitted responsibility for the failure $\left(\mathrm{M}_{\mathrm{DE}}=4.250, \mathrm{M}_{\mathrm{IDE}}=4.250, \mathrm{~F}_{(1,38)}\right.$ $=0.482, p>0.5)$. Regarding the other measurement questions, we made a few minor modifications to the wording and the question sequence according to the comments from the participants.

As to the formal test, according to the customer database provided by the Chongqing Branch of Uroaming Company and Chongqing New Century International Travel Agency, a total of 1083 Chinese tourists who have purchased Wi-Fi rental service in the past year were contacted through sent the questionnaire to these tourists' email from 1-12 June 2018, and 478 answered the questionnaire. Through the initial filter question "During the latest consumer experience, have you ever seeking the online customer service to resolve the service problem you have met", 149 participants did not pass the check, while 329 stated having experienced online recovery service.

Then, because 26 questionnaires were not completely answered, and to avoid demographic errors, we deleted 6 questioners which were answered by 4 young respondents ( $<20$ years) and 2 old respondents ( $>50$ years), this resulted in a total of 297 valid responses that have been used in the data analysis. Table 3 describes the demographics of the sample.

Moreover, the results also shown, $80.14 \%$ of participants last purchased the service product 6 months ago, which effectively reduced the retrospective self report bias due to memory loss [45]. And $50.84 \%$ of participants $(\mathrm{N}=151)$ thought that the service staff used direct expression mode, while the others $(\mathrm{N}=146)$ thought the service staff used indirect expression mode. 
Table 3. Demographic information of respondents $(\mathrm{N}=297)$.

\begin{tabular}{lcc}
\hline \multicolumn{1}{c}{ Variables } & Frequency & Percentage \\
\hline Sex & & \\
\hline Male & 145 & $48.82 \%$ \\
Female & 152 & $51.18 \%$ \\
\hline Nationality & & \\
$\quad$ Chinese & 297 & $100 \%$ \\
\hline Age & & \\
20-35 & 268 & $90.24 \%$ \\
35-50 & 29 & $9.76 \%$ \\
\hline Mother tongue & & \\
Chinese & 297 & $100 \%$ \\
\hline Occupation & & \\
Full-time student & 23 & $7.74 \%$ \\
Production & 29 & $9.76 \%$ \\
Market/Public relations & 26 & $8.75 \%$ \\
Customer service & 32 & $10.77 \%$ \\
Sales & 27 & $9.09 \%$ \\
Administration/Logistics & 16 & $5.39 \%$ \\
Human resources & 27 & $9.09 \%$ \\
Financial/auditor & 19 & $6.40 \%$ \\
Civilian/clerk & 12 & $4.04 \%$ \\
Technology/ Research and Development & 14 & $4.71 \%$ \\
Manager & 13 & $4.38 \%$ \\
Teacher & 18 & $6.06 \%$ \\
Consultant & 20 & $6.73 \%$ \\
Professional & 14 & $4.71 \%$ \\
Others & 7 & $2.36 \%$ \\
\hline$\quad$ & &
\end{tabular}

\subsection{Data Analysis and Results}

Partial least squares structural equation modeling (PLS-SEM) is a preferred analytical tool for behavioral research for objects of inquiry such as the attitude or personality traits of customers since it can estimate the overall goodness of fit and approximate fit of the factor model and provide evidence of the quality of the measurement [61]. Because our measures have a behavioral nature, the proposed research model was tested through PLS-SEM analysis using SmartPLS 3.2.6 software. Additionally, we used partial least squares multi analysis (PLS-MGA) to verify the moderation role of the expression modes of apology.

\subsection{Overall Model Assessment}

The tests of overall model fit included two parts, that is, tests of the model fit and the approximate mode fit. The results of the main likelihood discrepancy, the geodesic discrepancy $\left(\mathrm{d}_{\mathrm{G}}=0.041\right)$ and the unweighted least squares discrepancy $\left(\mathrm{d}_{\mathrm{ULS}}=0.043\right)$ between the empirical and model-implied correction matrix, which rely on bootstrap-based tests, can be used to assess the overall goodness of fit of the model $[62,63]$. The standardized root mean square residual (SRMR $=0.023$ ) was under the cutoff threshold of 0.08; thus, the overall goodness of fit of the model was verified, indicating that the data were coherent with the model [63].

\subsection{Measurement Model Assessment}

The adequacy of the measurement model was evaluated based on the criteria of internal consistency reliability, convergent validity, and discriminant validity. Table 4 shows that the Dijkstra-Henseler's rho $\rho_{A}$, Dillon-Goldstein's $\rho_{C}$ and Cronbach's $\alpha$ of all individual scale items exceed the minimum value of 0.7 , indicating adequate reliability $[61,63]$. The convergent validity of the constructs was also shown to be satisfactory, with an average variance explained (AVE) exceeding 0.5 (see Table 4) in all cases and all loadings exceeding 0.7 [64] (see Table 5). 
Table 4. Reliability and validity of construct measurement.

\begin{tabular}{|c|c|c|c|c|c|c|c|c|c|c|c|c|c|c|}
\hline \multirow{2}{*}{ Item } & \multirow{2}{*}{ Measurement } & \multirow{2}{*}{ Source } & \multicolumn{4}{|l|}{ All s } & \multicolumn{4}{|l|}{1} & \multicolumn{4}{|l|}{2} \\
\hline & & & $\alpha$ & AVE & $\rho_{\mathrm{C}}$ & $\rho_{\mathrm{A}}$ & $\alpha$ & AVE & $\rho_{\mathrm{C}}$ & $\rho_{\mathrm{A}}$ & $\alpha$ & AVE & $\rho_{\mathrm{C}}$ & $\rho_{\mathrm{A}}$ \\
\hline $\begin{array}{l}\text { EP1 } \\
\text { EP2 } \\
\text { EP3 }\end{array}$ & $\begin{array}{l}\text { I try to be cooperative with the staff. } \\
\text { I am friendly to the staff. } \\
\text { I respect the staff. }\end{array}$ & $\begin{array}{l}\text { Chen and Raab [11]; } \\
\text { Kuo et al. [40] }\end{array}$ & 0.704 & 0.586 & 0.807 & 0.723 & 0.701 & 0.519 & 0.750 & 0.713 & 0.702 & 0.570 & 0.791 & 0.729 \\
\hline $\begin{array}{l}\text { MP1 } \\
\text { MP2 }\end{array}$ & $\begin{array}{l}\text { I read reviews of other customers about the } \\
\text { problem which I have met. } \\
\text { I spend time searching for information about } \\
\text { the problem. }\end{array}$ & Chen and Raab [40] & 0.722 & 0.782 & 0.878 & 0.722 & 0.749 & 0.791 & 0.883 & 0.874 & 0.733 & 0.731 & 0.845 & 0.736 \\
\hline $\begin{array}{l}\text { PP1 } \\
\text { PP2 } \\
\text { PP3 }\end{array}$ & $\begin{array}{l}\text { I initiate a dialogue when I met problem. } \\
\text { I ask questions if I do not know how to resolve } \\
\text { the problem. } \\
\text { I openly discuss questions and concerns about the } \\
\text { problem with the staff. }\end{array}$ & Chen and Raab [40] & 0.726 & 0.640 & 0.842 & 0.772 & 0.739 & 0.634 & 0.837 & 0.899 & 0.754 & 0.591 & 0.812 & 0.754 \\
\hline $\begin{array}{l}\text { PJ1 } \\
\text { PJ2 } \\
\text { PJ3 } \\
\text { PJ4 }\end{array}$ & $\begin{array}{l}\text { The outcome received was fair. } \\
\text { I got what I deserved. } \\
\text { In resolving the problem, the service staff gave me } \\
\text { what I needed } \\
\text { The outcome that I received was right. }\end{array}$ & Park and Ha [44] & 0.887 & 0.746 & 0.921 & 0.893 & 0.796 & 0.649 & 0.878 & 0.792 & 0.798 & 0.561 & 0.707 & 0.731 \\
\hline $\begin{array}{l}\text { SAT1 } \\
\text { SAT2 } \\
\text { SAT3 }\end{array}$ & $\begin{array}{l}\text { I am satisfied with the way my problem was dealt } \\
\text { with and resolved. } \\
\text { The staff provided a satisfactory solution to this } \\
\text { particular problem. } \\
\text { I am happy with the way my problem was solved. }\end{array}$ & Lii et al. [20] & 0.805 & 0.720 & 0.885 & 0.806 & 0.818 & 0.691 & 0.869 & 0.901 & 0.709 & 0.561 & 0.793 & 0.710 \\
\hline
\end{tabular}

Note: $\mathrm{EP}$ = emotional participation; $\mathrm{MP}$ = mental participation; $\mathrm{PP}$ = physical participation; $\mathrm{PJ}$ = perceived justice; $\mathrm{SAT}$ = post-recovery satisfaction; $\mathrm{AVE}$ = average variance explained. 
Discriminant validity was confirmed using the following three tests. First, the pattern of the cross-factor loadings shows that the loading of each measurement item on its assigned latent variable is larger than its loading on any other construct [63] (see Table 5). Second, the square root of the AVE value of a construct is larger than all correlations between the construct and other constructs in the model [64] (see Table 5). Third, the heterotrait-monotrait (HTMT) ratio of correlations values between perceived justice and satisfaction are 0.539 (all), 0.191 (1), and 0.767 (2); all of these values are significantly less than 0.8 , providing sufficient evidence of the discriminant validity of a pair of constructs [63]. Consequently, the results of all tests were satisfactory, and discriminant validity was verified [61].

Table 5. Standardized factor loadings, cross-factor loadings of study and inter-construct correlations.

\begin{tabular}{llllll}
\hline Item & EP & MP & PP & PJ & SAT \\
\hline EP1 & $\mathbf{0 . 7 9 8}$ & 0.377 & 0.396 & 0.131 & 0.338 \\
EP2 & $\mathbf{0 . 8 5 0}$ & 0.362 & 0.475 & 0.161 & 0.245 \\
EP3 & $\mathbf{0 . 7 0 3}$ & 0.221 & 0.337 & 0.070 & 0.226 \\
\hline MP1 & 0.358 & $\mathbf{0 . 8 8 6}$ & 0.531 & 0.297 & 0.516 \\
MP2 & 0.404 & $\mathbf{0 . 8 8 3}$ & 0.569 & 0.293 & 0.541 \\
\hline PP1 & 0.422 & 0.512 & $\mathbf{0 . 7 6 1}$ & 0.180 & 0.491 \\
PP2 & 0.454 & 0.556 & $\mathbf{0 . 8 6 5}$ & 0.308 & 0.494 \\
PP3 & 0.405 & 0.422 & $\mathbf{0 . 7 7 1}$ & 0.228 & 0.427 \\
\hline PJ1 & 0.153 & 0.212 & 0.196 & $\mathbf{0 . 8 4 8}$ & 0.368 \\
PJ2 & 0.144 & 0.272 & 0.248 & $\mathbf{0 . 8 8 1}$ & 0.381 \\
PJ3 & 0.164 & 0.309 & 0.323 & $\mathbf{0 . 8 6 8}$ & 0.409 \\
PJ4 & 0.120 & 0.341 & 0.285 & $\mathbf{0 . 8 5 7}$ & 0.417 \\
\hline SAT1 & 0.280 & 0.509 & 0.424 & 0.379 & $\mathbf{0 . 8 3 9}$ \\
SAT2 & 0.234 & 0.457 & 0.490 & 0.399 & $\mathbf{0 . 8 5 2}$ \\
SAT3 & 0.374 & 0.556 & 0.570 & 0.387 & $\mathbf{0 . 8 5 4}$ \\
\hline EP & 0.766 & & & & \\
MP & 0.431 & 0.885 & & & \\
PP & 0.532 & 0.621 & 0.800 & & \\
PJ & 0.168 & 0.333 & 0.310 & 0.864 & \\
SAT & 0.348 & 0.597 & 0.583 & 0.458 & 0.848 \\
\hline
\end{tabular}

Note: 1. Each item's loadings are expressed in bold type. 2. Diagonal elements show the square root of AVE for each construct. Numbers below diagonal are correlations between constructs.

Furthermore, a post hoc Harman's single factor test was used to access common method bias. The result shown a single factor did not emerge from the unrotated solution, which means the common bias was low. The total variance of the single factor model accounted for $27.65 \%$ of total variance. Accordingly, we concluded all the constructs in this study have acceptable reliability and validity.

\subsection{Structural Model and Hypotheses}

A PLS-SEM bootstrapping approach was used to test the hypotheses with 10,000 bootstrap samples. The results are given in Table 6. First, the perceived justice-satisfaction model accounted for $66 \%$ of the explained variance of satisfaction in online recovery $\left(R^{2}=63 \%\right)$. The levels of explained variance for perceived justice $\left(\mathrm{R}^{2}=47.5 \%\right)$ accounted for by the customer participation components are acceptable as well. Thus, the fit of the overall model is acceptable.

Second, the path coefficients and confidence intervals (CIs) show that emotional participation has no positive effect on informational justice; thus, H1a is supported. Mental participation positively influences perceived justice; thus, $\mathrm{H} 1 \mathrm{~b}$ is supported. Physical participation positively influences perceived justice; thus, H1c is supported. Perceived justice positively influences customers' post-recovery satisfaction; thus, $\mathrm{H} 3$ is supported. 
Table 6. Structural model results.

\begin{tabular}{|c|c|c|c|c|c|c|c|}
\hline \multirow{2}{*}{ Dependent Variable } & \multirow{2}{*}{ Independent Variable } & \multirow{2}{*}{$p$-Value } & \multicolumn{2}{|c|}{ Confidence Intervals } & \multirow{2}{*}{$t$-Value } & \multirow{2}{*}{ SD } & \multirow{2}{*}{$\mathbf{R}^{2}$} \\
\hline & & & $2.5 \%$ & $97.5 \%$ & & & \\
\hline \multirow{3}{*}{ PJ } & $\mathrm{EP}$ & 0.625 & -0.113 & 0.099 & 0.489 & 0.059 & \\
\hline & MP & 0.001 & 0.087 & 0.356 & 3.267 & 0.072 & 0.475 \\
\hline & PP & 0.025 & 0.024 & 0.334 & 2.252 & 0.080 & \\
\hline SAT & PJ & 0.000 & 0.386 & 0.542 & 11.210 & 0.041 & 0.630 \\
\hline
\end{tabular}

Note: $\mathrm{EP}=$ emotional participation; $\mathrm{MP}=$ mental participation; $\mathrm{PP}$ = physical participation; $\mathrm{PJ}$ = perceived justice; $\mathrm{SAT}=$ post-recovery satisfaction

\subsection{Mediation Effects}

Following Nitzl, Roldan, and Cepeda [65], we used a two-step method to verify the mediating role of perceived justice. First, a bootstrap analysis with 10,000 samples was performed for the model; the analysis also set lines connecting physical participation and satisfaction, and mental participation and satisfaction. Then, the results of total effect and direct effect were calculated using SmartPLS 3.2.6 software. For the direct effect of PP $\rightarrow$ SAT is significant $(t=4.281, p=0.000<0.001)$, and the indirect effect of PP $\rightarrow$ SAT though PJ is significant $(t=2.002, p=0.045<0.05)$, the $95 \%$ percentile CI of $\mathrm{PP} \rightarrow$ SAT through PJ $([0.004,0.091])$ does not include 0 , thus PJ partially mediates PP $\rightarrow$ SAT. The direct effect of MP $\rightarrow$ SAT is significant $(t=5.200, p=0.000<0.001)$, and the indirect effect of MP $\rightarrow$ SAT though PJ is significant $(t=2.840, p=0.005<0.01)$, the $95 \%$ percentile CI of MP $\rightarrow$ SAT through PJ $([0.022,0.109])$ does not include 0 , thus PJ partially mediates MP $\rightarrow$ SAT.

\subsection{Partial Least Squares Multi Analysis (PLS-MGA): The Moderation Role of the Expressions of the Apology}

Our method of PLS-MGA followed that of Matthews [66]. First, the SRMR, $\mathrm{d}_{\mathrm{ULS}}$ and $\mathrm{d}_{\mathrm{G}}$ of group 1 are $0.025,0.032,0.057$, and group 2 are $0.045,0.056$, and 0.045 which means the overall goodness of fit of two groups' model was verified. And the results of Table 4 also provide clear support for the measures' reliability and validity [66].

Second, we use the measurement invariance of composite models (MICOM) procedure to test the measurement invariance for all groups. Configural invariance was fulfilled since the measurement models for the two groups meet the three requirements of "identical indicators per measurement model, identical data treatment, and identical algorithm settings criteria" [66]. Then, a permutation test was executed to verify compositional invariance. A permutation test was set at 5000 samples, and the test type was set as two-tailed with a significance level of 0.05 . As shown in Table 7, the original correlations are equal to or greater than the $5.00 \%$ quantile correlations (shown in the $5 \%$ column), indicating that compositional invariance has been demonstrated for all the constructs [66]. The data in the mean original difference column fall within the $95 \% \mathrm{CI}$, and the permutation $p$-values are greater than 0.05 , indicating that the construct passes the variance test. The data in the variance original difference column fall within the $95 \% \mathrm{CI}$, and the permutation $p$-values are greater than 0.05 , further indicating that the entire construct passes the measurement variance test [66].

Third, since invariance is verified, we first analyze the groups separately to determine whether there is a difference between the two groups. Table 8 shows the bootstrap results of each of the two groups with 5000 sub-samples. As the last column of Table 7 shows, the permutation $p$-values of the three types of customer participation and perceived justice are all less than 0.10 , indicating that these three relationships have significant differences between the two groups [66].

To further verify the analysis results according to the permutation test, we use the MGA algorithm to check the differences between the two groups. Table 8 shows the results of the test of CIs, which is a non-parametric test. The criteria establish that if the parameter coefficient for a path relationship of one group (see Table 8) does not fall within the corresponding CI of another group (Table 8) and vice versa, then there exists no overlap, and we can assume that there is a significant difference between the two groups [66]. Thus, according to Table $8, \mathrm{H} 2 \mathrm{~b}$ and $\mathrm{H} 2 \mathrm{c}$ are verified; however, emotional participation does not influence perceived justice in either direct or indirect situations; thus, H2a is not verified. 
Table 7. Results of measurement invariance of composite models (MICOM) permutation test.

\begin{tabular}{|c|c|c|c|c|c|c|c|c|c|c|c|c|c|c|}
\hline & \multicolumn{4}{|l|}{ Part I } & \multicolumn{5}{|l|}{ Part II } & \multicolumn{5}{|l|}{ Part III } \\
\hline & \multirow[b]{2}{*}{$\begin{array}{l}\text { Original } \\
\text { Correlation }\end{array}$} & \multirow[b]{2}{*}{$\begin{array}{l}\text { Correlation } \\
\text { Permutation } \\
\text { Mean }\end{array}$} & \multirow[b]{2}{*}{$5.00 \%$} & \multirow[b]{2}{*}{$\begin{array}{l}\text { Permutation } \\
p \text {-Values }\end{array}$} & \multicolumn{2}{|l|}{ Mean } & \multirow[b]{2}{*}{$2.50 \%$} & \multirow[b]{2}{*}{$97.50 \%$} & \multirow[b]{2}{*}{$\begin{array}{l}\text { Permutation } \\
p \text {-Values }\end{array}$} & \multicolumn{2}{|l|}{ Variance } & \multirow[b]{2}{*}{$2.50 \%$} & \multirow[b]{2}{*}{$97.50 \%$} & \multirow[b]{2}{*}{$\begin{array}{l}\text { Permutation } \\
p \text {-Values }\end{array}$} \\
\hline & & & & & $\begin{array}{l}\text { Original } \\
\text { Difference }\end{array}$ & $\begin{array}{l}\text { Permutation } \\
\text { Mean } \\
\text { Difference }\end{array}$ & & & & $\begin{array}{l}\text { Original } \\
\text { Difference }\end{array}$ & $\begin{array}{l}\text { Permutation } \\
\text { Mean } \\
\text { Difference }\end{array}$ & & & \\
\hline EP & 0.971 & 0.897 & 0.967 & 0.705 & 0.155 & -0.005 & -0.215 & 0.240 & 0.169 & -0.047 & -0.002 & -0.358 & 0.345 & 0.793 \\
\hline MP & 0.989 & 0.996 & 0.985 & 0.102 & 0.148 & 0.005 & -0.233 & 0.224 & 0.228 & -0.105 & -0.011 & -0.395 & 0.349 & 0.059 \\
\hline PP & 0.976 & 0.985 & 0.954 & 0.189 & 0.009 & 0.002 & -0.236 & 0.225 & 0.991 & -0.153 & -0.004 & -0.431 & 0.400 & 0.188 \\
\hline PJ & 0.984 & 0.994 & 0.982 & 0.078 & 0.087 & 0.003 & -0.231 & 0.234 & 0.499 & -0.126 & -0.001 & -0.174 & 0.176 & 0.323 \\
\hline
\end{tabular}

Note: $\mathrm{EP}=$ emotional participation; $\mathrm{MP}$ = mental participation; $\mathrm{PP}$ = physical participation; $\mathrm{PJ}$ = perceived justice.

Table 8. Permutation test path coefficient results and Multigroup Comparison Results.

\begin{tabular}{|c|c|c|c|c|c|c|c|c|c|c|c|c|c|c|c|}
\hline & \multicolumn{4}{|c|}{ Path Coefficients } & \multicolumn{2}{|l|}{$t$-Values } & \multicolumn{2}{|l|}{$p$-Values } & \multirow{3}{*}{$2.50 \%$} & \multirow{3}{*}{$97.50 \%$} & \multirow{3}{*}{$\begin{array}{l}\text { Permutation } \\
p \text {-Values }\end{array}$} & \multicolumn{4}{|c|}{ Confidence Intervals } \\
\hline & \multirow{2}{*}{ Group 1} & \multirow{2}{*}{ Group 2} & \multirow{2}{*}{$\begin{array}{l}\text { Original } \\
\text { Difference }\end{array}$} & \multirow{2}{*}{$\begin{array}{l}\text { Permutation } \\
\text { Mean } \\
\text { Difference }\end{array}$} & \multirow{2}{*}{ Group 1} & \multirow{2}{*}{ Group 2} & \multirow{2}{*}{ Group 1} & \multirow{2}{*}{ Group 2} & & & & \multicolumn{2}{|c|}{ Group 1} & \multicolumn{2}{|c|}{ Group 2} \\
\hline & & & & & & & & & & & & $2.50 \%$ & $97.50 \%$ & $2.50 \%$ & $97.50 \%$ \\
\hline $\mathrm{EP} \rightarrow \mathrm{PJ}$ & 0.031 & 0.285 & -0.253 & -0.000 & 0.436 & 1.759 & 0.663 & 0.079 & -0.213 & 0.206 & 0.021 & -0.134 & 0.148 & -0.146 & 0.495 \\
\hline $\mathrm{MP} \rightarrow \mathrm{PJ}$ & 0.098 & 0.358 & -0.260 & 0.004 & 0.635 & 3.340 & 0.526 & 0.001 & -0.262 & 0.293 & 0.067 & -0.395 & 0.309 & 0.127 & 0.549 \\
\hline $\mathrm{PP} \rightarrow \mathrm{PJ}$ & -0.115 & 0.224 & -0.338 & -0.003 & 0.695 & 2.142 & 0.488 & 0.033 & -0.293 & 0.272 & 0.024 & -0.610 & 0.095 & -0.018 & 0.405 \\
\hline
\end{tabular}

Note: Group 1 = Direct Expression; Group 2 = Indirect Expression. 


\section{Research Findings and Discussion}

This study proposes a model that interprets the mechanisms at play in customer participation within the online recovery process by examining how the three dimensions of customer participation-mental, physical, and emotional-affect post-recovery satisfaction in terms of perceived justice (a mediating effect). This study is also the first to explore the influence of online interactive language factors on online recovery by explaining the moderating role of two types of apology speech acts in customer participation and perceived justice. This research provides some important findings.

First, the three dimensions of customer participation have different influences on perceived justice in online recovery. That is, during online recovery, only customers' metal and physical behavior can enhance their fairness perception of recovery, while customers' emotional behavior does not influence perceived justice. This finding is not consistent with that of Kuo et al. [37], who concluded that each type of customer participation can produce positive service outcomes that reduce customers' complaints about service failure. The reason may be that this study is focused on customer participation in service recovery, while Kuo et al. [37] focused on customer participation in service production. This finding suggests that perhaps different customer participation behaviors at different service stages may produce different effects on service outcomes, and it may be imprecise to directly cite the empirical conclusions of customer participation without considering the research setting and specific service stage. On the other hand, this inconsistent finding also may be caused by cultural difference. By contrast with western culture, which encourages emotional expression, Chinese culture encourages emotional suppression. Chinese traditional culture always hopes that individuals can rationally restrain emotions, and does not arbitrarily express emotions, so as not to lead to tension or breakdown of interpersonal relationships [67]. Thus, when the Chinese customers feel unpleasant emotions caused by the service failure, they will try to restrain emotions. However, emotional suppression always brings more pressure [56,57], which does not positively affect service outcomes [31], thus, in this study, a customer's emotional participation cannot improve perceived justice.

Second, our findings explain why customers may hide their discomfort over service failure when facing service staff but tend to talk about the service failure experience to third parties, such as on social media and among friends [37]. The reason is that when customers control their emotions to express politeness and patience, they strongly feel a resource loss [56]; thus, compared to the other types of customer participation, emotional participation will make them want a corresponding return from service staff more due to resource imbalance, and when the return is not expected, they will feel pressure [57]. Therefore, to recover resource balance and to release stress, customers will want to express dissatisfaction with the service to third parties. Doing so can be treated as a means of venting their anger, establishing some sort of balance or justice caused by emotional participation.

Third, the positive influence of mental participation on perceived justice is the most significant, which shows that customers label their resources for different mental accounts. Currently, as a result of the value and industrialization of knowledge, mental labor holds the core position in management and production organization as well as in the upper reaches of the industrial chain. In China, people tend to regard mental labor as a higher-level form of labor, and they recognize the value of mental labor more but always undervalue physical labor [68], which is similar to the phenomenon of "sweat equity" [43]. As a result, compared with physical labor, when customers input mental labor to push the recovery process and turn it into a cooperative process and when they find the optimum resolution to remedy the situation through the collaborative engagement between the two parties, they will feel more mastery, competence, and efficacy over the impending harm caused by the service failure, which will enhance their perception of the justice of the service recovery [41].

Fourth, the expression mode of online apology speech acts (direct and indirect) moderates the relationship between customer participation and perceived justice. Only in the indirect expression situation do mental participation and physical participation have a positive effect on perceived justice. The reason is that sincerity represents the service staff's emotional response, which is the core meaning of the apology [53] and is most likely to produce a forgiving response from customers [15,49,51]. Thus, 
when service staff use an indirect expression to show their empathy and sincerity, this usage can strike a responsive chord with the customer with regard to the service failure and then promote the customer's acceptance of the expression and way of handling the situation of the service provider, making the customer feel that he/she has received positive feedback to restore resource balance and resulting in higher perceived justice. However, because it lacks empathetic significance, a direct expression of apology will cause the customer to doubt the sincerity of the service provider's regret [14] and then amplify the pressure generated by resource imbalance, resulting in a lower perception of justice.

\section{Conclusions}

\subsection{Managerial Implications}

The results of this study provide suggestions for online service providers regarding the improvement of online recovery management. First, service providers can improve positive perceptions of justice through a proper design to encourage customers' mental and physical participation in online recovery, improving customers' post-recovery satisfaction. For example, the "flying pig", which is a popular OTA (Online Travel Agency) platform in China, improves customers' ability to initiate online recovery and solve problems autonomously by presenting links regarding similar problems, which can motivate customers to take the initiative to collect and exchange information and initiate a dialogue with service staff.

Second, service providers should pay more attention to polite customers since they are good at concealing their true thoughts when faced with service staff and are also good at finding other channels to vent their anger about the unfair treatment in service recovery. Thus, when customers input emotional labor in the service recovery, service staff should provide more positive feedback, and after the service remedy is completed, a return visit should also be conducted to further understand the true thoughts of customers.

Third, service providers should do their best to maintain customers' resource balance and prevent customers from thinking that investing resources is a waste or is not worth it. Thus, they can convey positive feedback by expressing their apologies by using indirect expressions such as emojis to improve the overall sense of perceived justice.

\subsection{Limitations and Further Research}

There are several limitations to this study. First, the study did not consider the impact of different platforms or devices on the expression of emojis since Danesi [18] noted that "the exact appearance of emojis is not fixed, but varies between platforms or devices, in the same way that normal typefaces do" and because emojis may accrue unexpected meanings. Therefore, in a next step, we can discuss the impact of the use of emojis on online recovery performance based on different devices and different platforms. Second, the study discussed the online recovery scenario only for Wi-Fi rental services. Future research can extend the research area to airline ticket online booking, hotels, and visa services and identify more factors that affect online service recovery performance. Third, this study did not explore the moderating role of different service failure types; however, different values are assigned to different types of failures (process vs. outcome) [45]. Thus, service types will influence customers' different labeling of their service, and further research can expand on this point. Fourth, the collected data used in the study has been gathered in China, and future studies are advised to test the proposed theory-driven framework considering different populations in diverse cultures. Fifth, the sample size of this study was small, and most of the respondents were aged 20-35 years; thus, further study can expand the sample number to increase the degree to which the empirical results are convincing.

Author Contributions: The authors declare the following roles during the development of the present paper. Conceptualization, Y.Z. and B.S.; Methodology, Y.Z.; Formal Analysis, Y.Z.; Investigation, Y.Z.; Data Curation, Y.Z.; Writing-Original Draft Preparation, Y.Z.; Writing-Review \& Editing, B.S.; Supervision, B.S.; Project Administration, B.S.; Funding Acquisition, B.S. 
Funding: This research was funded by the National Social Science Foundation of China grant number [No.14AGL023].

Conflicts of Interest: The authors declare no conflict of interest.

\section{References}

1. Weitzl, W.; Hutzinger, C. The effects of marketer- and advocate-initiated online service recovery responses on silent bystanders. J. Bus. Res. 2017, 80, 164-175. [CrossRef]

2. Gohary, A.; Hamzelu, B.; Alizadeh, H. Please explain why it happened! How perceived justice and customer involvement affect post co-recovery evaluations: A study of Iranian online shoppers. J. Retail. Consum. Serv. 2016, 31, 127-142. [CrossRef]

3. Li, C.Y.; Fang, Y.H. How online service recovery approaches bolster recovery performance? a multi-level perspective. Serv. Bus. 2016, 10, 1-22. [CrossRef]

4. Manika, D.; Papagiannidis, S.; Bourlakis, M. Understanding the effects of a social media service failure apology: A comparative study of customers vs. potential customers. Int. J. Inf. Manag. 2017, 37, $214-228$. [CrossRef]

5. Kuo, Y.F.; Wu, C.M. Satisfaction and post-purchase intentions with service recovery of online shopping websites: Perspectives on perceived justice and emotions. Int. J. Inf. Manag. 2012, 32, 127-138. [CrossRef]

6. Chuang, S.C.; Cheng, Y.H.; Chang, C.J.; Yang, S.W. The effect of service failure types and service recovery on customer satisfaction: A mental accounting perspective. Serv. Ind. J. 2012, 32, 257-271. [CrossRef]

7. Lii, Y.S.; Chien, C.S.; Pant, A.; Lee, M. The challenges of long-distance relationships: The effects of psychological distance between service provider and consumer on the efforts to recover from service failure. J. Appl. Soc. Psychol. 2013, 43, 1121-1135. [CrossRef]

8. Chua, C.; Sweeney, J.C. Customer participation in service production: Development of a multidimensional scale. In Proceedings of the Anzmac 2003 Conference, South Australia, Australia, 1-3 December 2003.

9. Yi, Y.; Gong, T. Customer value co-creation behavior: Scale development and validation. J. Bus. Res. 2013, 66, 1279-1284. [CrossRef]

10. Chen, S.C.; Raab, C. Construction and Validation of the Customer Participation Scale. J. Hosp. Tour. Res. 2017, 41, 131-153. [CrossRef]

11. Dong, B.; Sivakumar, K. Customer participation in services: Domain, scope, and boundaries. J. Acad. Mark. Sci. 2017, 45, 1-22. [CrossRef]

12. Ranjan, K.R.; Read, S. Value co-creation: Concept and measurement. J. Acad. Mark. Sci. 2016, 44, $290-315$. [CrossRef]

13. Thaler, R.H. Mental accounting matters. J. Behav. Decis. Mak. 1999, 12, 183-206. [CrossRef]

14. Roschk, H.; Kaiser, S. The nature of an apology: An experimental study on how to apologize after a service failure. Mark. Lett. 2013, 24, 293-309. [CrossRef]

15. Vázquez-Casielles, R.; Iglesias, V.; Varela-Neira, C. Co-creation and service recovery process communication: Effects on satisfaction, repurchase intentions, and word of mouth. Serv. Bus. 2016, 11, 1-23. [CrossRef]

16. Vaerenbergh, Y.V.; Orsingher, C. Service recovery: An integrative framework and research agenda. Acad. Manag. Executive 2016, 30, 328-346. [CrossRef]

17. Park, J.R. Linguistic politeness and face-work in computer-mediated communication, Part 1: A theoretical framework. J. Am. Soc. Inf. Sci. Technol. 2018, 59, 2051-2059. [CrossRef]

18. Danesi, M. The Semiotics of Emoji: The Rise of Visual Language in the Age of the Internet, 1st ed.; Bloomsbury Academic: London, UK, 2017; ISBN 13: 9781474281980.

19. Dabholkar, P.A. How to improve perceived service quality by increasing customer participation. In Development in Marketing Science; Dradley, J.D., Ed.; Academy of Marketing Science: Cullowhee, CA, USA, 1990; pp. 483-487.

20. Minkiewicz, J.; Evans, J.; Bridson, K. How do consumers co-create their experiences? An exploration in the heritage sector. J. Mark. Manag. 2014, 30, 30-59. [CrossRef]

21. Prebensen, N.K.; Xie, J. Efficacy of co-creation and mastering on perceived value and satisfaction in tourists' consumption. Tour. Manag. 2017, 60, 166-176. [CrossRef]

22. Uzkurt, C. Customer participation in the service process: A model and research propositions. Int. J. Serv. Oper. Manag. 2010, 6, 17-37. [CrossRef] 
23. Silpakit, P.; Fisk, R. Participating the service encounter: A Theoretical Framework. In Service Marketing in a Changing Environment; Block, T.M., Upah, G.D., Zeithmal, V.A., Eds.; American Marketing Association: Chicago, IL, USA, 1985.

24. Hazée, S.; Vaerenbergh, Y.V.; Armirotto, V. Co-creating service recovery after service failure: The role of brand equity. J. Bus. Res. 2017, 74, 101-109. [CrossRef]

25. Roggeveen, A.L.; Tsiros, M.; Grewal, D. Understanding the co-creation effect: When does collaborating with customers provide a lift to service recovery? J. Acad. Mark. Sci. 2012, 40, 771-790. [CrossRef]

26. Bendapudi, N.; Leone, R.P. Psychological Implications of Customer Participation in Co-Production. J. Mark. 2003, 67, 14-28. [CrossRef]

27. Haumann, T.; Güntürkün, P.; Schons, L.M.; Wieseke, J. Engaging customers in coproduction processes: How value-enhancing and. J. Mark. 2015, 79, 17-33. [CrossRef]

28. Cheung, F.Y.M.; To, W.M. A customer-dominant logic on service recovery and customer satisfaction. Manag. Decis. 2016, 54, 2524-2543. [CrossRef]

29. Claycomb, C.; Lengick-Hall, C.A.; Inks, L.W. The customer as a productive resource: A pilot study and strategic implications. J. Bus. Strateg. 2001, 18, 47-69.

30. Dong, B.; Evans, K.R.; Zou, S. The effects of customer participation in co-created service recovery. J. Acad. Mark. Sci. 2008, 36, 123-137. [CrossRef]

31. Dong, B.; Sivakumar, K.; Evans, K.R.; Zou, S. Recovering Coproduced Service Failures: Antecedents, Consequences, and Moderators of Locus of Recovery. J. Serv. Res. 2016, 19, 291-306. [CrossRef]

32. Dong, B.; Sivakumar, K.; Evans, K.R.; Zou, S. Effect of Customer Participation on Service Outcomes: The Moderating Role of Participation Readiness. J. Serv. Res. 2014, 18, 160-176. [CrossRef]

33. Heidenreich, S.; Wittkowski, K.; Handrich, M.; Falk, T. The dark side of customer co-creation: Exploring the consequences of failed co-created services. J. Acad. Mark. Sci. 2015, 43, 279-296. [CrossRef]

34. Xu, Y.Z.; Marshall, R.; Edvardsson, B.; Tronvoll, B. Show you care: Initiating co-creation in service recovery. J. Serv. Manag. 2014, 25, 369-387. [CrossRef]

35. Yi, Y.; Nataraajan, R.; Gong, T. Customer participation and citizenship behavioral influences on employee performance, satisfaction, commitment, and turnover intention. J. Bus. Res. 2011, 64, 87-95. [CrossRef]

36. Zhu, Z.; Nakata, C.; Sivakumar, K.; Grewal, D. Fix It or Leave It? Customer Recovery from Self-service Technology Failures. J. Retail. 2013, 89, 15-29. [CrossRef]

37. Koc, E.; Ulukoy, M.; Kilic, R.; Yumusak, R.; Bahar, R. The influence of customer participation on service failure perceptions. Total. Qual. Manag. Bus. Excell. 2017, 28, 390-404. [CrossRef]

38. Gohary, A.; Hamzelu, B.; Pourazizi, L. A little bit more value creation and a lot of less value destruction! Exploring service recovery paradox in value context: A study in travel industry. J. Hosp. Tour. Manag. 2016, 29, 189-203. [CrossRef]

39. Xu, Y.Z.; Tronvoll, B.; Edvardsson, B. Recovering service failure through resource integration. Serv. Ind. J. 2014, 34, 1253-1271. [CrossRef]

40. Gohary, A.; Hamzelu, B.; Pourazizi, L.; Hanzaee, K.H. Understanding effects of co-creation on cognitive, affective and behavioral evaluations in service recovery: An ethnocultural analysis. J. Retail. Consum. Serv. 2016, 31, 182-198. [CrossRef]

41. Park, J.; Ha, S. Co-creation of service recovery: Utilitarian and hedonic value and post-recovery responses. J. Retail. Consum. Serv. 2016, 28, 310-316. [CrossRef]

42. Guo, L.; Lotz, S.L.; Gruen, T.W.; Tang, C. The role of perceived control in customer value cocreation and service recovery evaluation. J. Serv. Res. 2016, 19, 39-56. [CrossRef]

43. Ramesh, A.; Dew, N.; Read, S. The mental accounting of resource tradeoffs during the entrepreneurial plunge decision. Acad. Manag. Annu. Meet. Proc. 2014, 1, 12141-12161. [CrossRef]

44. Henderson, P.; Peterson, R. Mental accounting and categorization. Organ. Behav. Hum. Decis. Process. 1992, 51, 92-117. [CrossRef]

45. Smith, A.K.; Bolton, R.N.; Wagner, J. A Model of Customer Satisfaction with Service Encounters Involving Failure and Recovery. J. Mark. Res. 1999, 36, 356-372. [CrossRef]

46. Prelec, D.; Loewenstein, G. The red and the black: Mental accounting of savings and debt. Mark. Sci. 1998, 17, 4-28. [CrossRef]

47. Austin, J.L. How to do Things with Words; Oxford University Press: London, UK, 1962. 
48. Searle, J.R. Speech Acts: An Essay in the Philosophy of Language; Cambridge University Press: Cambridge, UK, 1969.

49. Schlenker, B.R.; Darby, B.W. The Use of Apologies in Social Predicaments. Soc. Psychol. Q. 1981, 44, $271-278$. [CrossRef]

50. Blum-Kulka, S.; House, J.; Kasper, G. Cross-cultural pragmatics: Requests and apologies. Language 1989, $67,169$.

51. Schumann, K. An affirmed self and a better apology: The effect of self-affirmation on transgressors' responses to victims. J. Exp. Soc. Psychol. 2014, 54, 89-96. [CrossRef]

52. Gillespie, N.; Dietz, G.; Lockey, S. Organizational reintegration and trust repair after an integrity violation: A case study. Bus. Ethics Q. 2014, 24, 371-410. [CrossRef]

53. Toney, D.; Hayes, L. A behavioral analysis of apologies, forgiveness, and interpersonal conflict. Behav. Soc. Issues 2017, 26, 128-155. [CrossRef]

54. Birtch, T.A.; Chiang, F.F.T.; Esch, E.V. A social exchange theory framework for understanding the job characteristics-job outcomes relationship: The mediating role of psychological contract fulfillment. Int. J. Hum. Resour. Manag. 2016, 27, 1217-1236. [CrossRef]

55. Holtgraves, T. Language structure in social interaction: Perceptions of direct and indirect speech acts and interactants who use them. J. Personal. Soc. Psychol. 1986, 51, 305-313. [CrossRef]

56. Hochschild, A.R. The Managed Heart: Commercialization of Human Feeling; University of California Press: Berkeley, CA, USA, 1983.

57. Côté, S. A social interactional model of the effects of emotion regulation on Work Strain. Acad. Manag. Rev. 2005, 30, 509-530. [CrossRef]

58. Foa, E.B.; Foa, U.G. Resource Theory: Interpersonal Behavior as Exchange. In Social Exchange: Advances in Theory and Research; Kenneth, G., Martin, S.G., Richard, H.W., Eds.; Plenum Press: New York, NY, USA, 1980.

59. Jaeger, S.R.; Xia, Y.; Lee, P.Y.; Hunter, D.C.; Beresford, M.K.; Ares, G. Emoji questionnaires can be used with a range of population segments: Findings relating to age, gender and frequency of emoji/emoticon use. Food Qual. Preference 2017, 68, 397-410. [CrossRef]

60. Douglas, S.P.; Craig, C.S. Collaborative and iterative translation: An alternative approach to back translation. J. Int. Mark. 2007, 15, 30-43. [CrossRef]

61. Henseler, J. Bridging design and behavioral research with variance-based structural equation modeling. J. Advert. 2017, 46, 178-192. [CrossRef]

62. Dijkstra, T.K.; Henseler, J. Consistent and asymptotically normal pls estimators for linear structural equations. Comput. Stat. Data Anal. 2015, 81, 10-23. [CrossRef]

63. Henseler, J.; Hubona, G.; Ray, P.A. Using pls path modeling in new technology research: Updated guidelines. Ind. Manag. Data Syst. 2016, 116, 2-20. [CrossRef]

64. Fornell, C.; Larcker, D.F. Evaluating structural equation models with unobservable variables and measurement error. J. Mark. Res. 1981, 18, 39-50. [CrossRef]

65. Nitzl, C.; Roldan, J.L.; Cepeda, G. Mediation analysis in partial least squares path modeling: Helping researchers discuss more sophisticated models. Ind. Manag. Data Syst. 2016, 116, 1849-1864. [CrossRef]

66. Matthews, L. Applying Multi-Group Analysis in PLS-SEM: A Step by Step Process. In Partial Least Squares Path Modeling: Basic Concepts, Methodological Issues and Applications; Latan, H., Ed.; Springer: Noonan, Switzerland, 2017.

67. Potter, S.H. The cultural construction of emotion in rural Chinese social life. Ethos 2010, 16, 181-208. [CrossRef]

68. Chang, Z.F. Study on measurement of social value of labor. J. Jiangsu Univ. Sci. Technol. 2015, 15, 93-97.

(C) 2018 by the authors. Licensee MDPI, Basel, Switzerland. This article is an open access article distributed under the terms and conditions of the Creative Commons Attribution (CC BY) license (http:/ / creativecommons.org/licenses/by/4.0/). 